\title{
A Critical Review of Talent Management: A Research Agenda
}

\author{
Lindah Madegwa ${ }^{1}$, Muathe S.M.A (PhD) ${ }^{2}$ \\ ${ }^{1} \mathrm{PhD}$ Student, Kenyatta University, School of Business, Kenya \\ ${ }^{2}$ Associate Dean, Kenyatta University, School of Business, Kenya
}

\begin{abstract}
This is a critical review of talent management investigating the origin of talent management, the factors that have influenced its growth and adoption, and the theoretical frame work used in the studies and identified gaps on the concept. Talent management was found to have various definitions and none that is universally agreed upon as scholars adapt either the inclusive or the exclusive views of the concept. The theories backing studies in talent management were identified as the human capital theory, social capital theory and the resource based view and studies in talent management ranged from the case studies to cross sectional surveys and the desk research. Talent management was studied as an independentvariable in some of the studies and as a dependent variable in most of the studies examined for the purpose of this paper.
\end{abstract}

Keywords: Talent management, Talenting, War for Talent, Human Resources.

\section{Introduction}

The beginning of the $21^{\text {st }}$ century was a period of rapid technological development which led to a massive number of new products exceeding the individuals' capability to trace them. Employee competencies became the focus of researchers' attention (Ulrich, 1997). This is an employee, characterized by the sets of competencies (Motowidlo, 2003) who creates and maintain competitive advantage and guarantees 'the edge' to the company performance. Human Capital is a key resource to adapt organisations to worldwide competition and organisations therefore have to compete against each other to maintain operations and continue to grow (Gardner, 2002). Talent development is an essential part of progressive care for employees: developing people with their own ability to be creative, to experience, to gain knowledge and who have the will to work at a particular motivational level.

\subsection{Origin of Talent Management}

The term talent management was coined by McKinsey and company following a 1997 study. (Lewis and Heckman, 2006) view talent management as comprising of three different conceptions as follows; first, a collection of typical human resource department practices; second, the flow of human resources throughout the organisation and third, sourcing developing and rewarding employee talent. Talent management was later the title of a book by Ed Michaels, Helen Handfield-Jones, and Beth Axelrod, however, the connection between human resource development and organisational effectiveness has been established since the 1970s.As a concept talent management is difficult to define, since it can be viewed from various different perspectives which give varying interpretations to the same activities within different organisations. According to Mckinsey, talent is the sum of a person's abilities, his or her intrinsic gifts, skills, knowledge, experience, intelligence, judgement, attitude, character and drive. Which then means that talent refers to the best and brightest, and many organisations adopted this to refer to their top employees who rank at the top $10 \%-20 \%$.

In contrast to the definitions given above, Buckingham and Vosburgh (2001) define talent management as the art of recognizing where each employees' natural talent lie and figuring out how to help each employee develop the job specific skills and knowledge to turn these talents into real performance. (Ulrich, 2006) takes a holistic view, Talent equals competence, commitment and contribution. $\mathrm{He}$ defines competence as individuals having the knowledge, skills and values that are required for today and tomorrow. Recent studies show that single minded focus on $10 \%-20 \%$ of individuals in an organisation often backfires and reduces rather than enhances individuals, team and organisational performance.

\subsection{Factors Influencing Growth and Adoption of Talent Management}

There are various factors that have influenced the growth and adoption of talent management; first managing talent is a challenge to all organisations in the context of globalization irrespective of the country (Gardner, 2002). Moreover, the concern about the scarcity of talent is almost universal. Organisations around the world are competing for the same pool of talent. This is seen as a global labour market for talents. In fact research suggests that the vision and strategy of an organisation are as important as the people that eventually will drive the company into the future (Collins, 2001). Since recruitment is expensive, organisations favour internal recruitment where possible especially for the higher positions. When this is added to the possibility for an employee to have a career and advance in an organisation, is a motivating factor (Caretta, 1992). By finding and developing talent, a company will beat the competition with regards to market shares, profit and long term value (Branham, 2000). Shareholders, employees and workers' unions pressure business leaders to provide results and profits as well as a healthy and stimulating work environment respectively. In addition, everyone in an 


\section{International Journal of Science and Research (IJSR) \\ ISSN (Online): 2319-7064 \\ Index Copernicus Value (2013): 6.14 | Impact Factor (2014): 5.611}

organisation should be able to change and allow for entrepreneurship, innovation and growth. More firms ${ }^{\text {ce }}$ competitive advantage relies on intangible assets such as knowledge.

\section{Theoretical Review}

Talent management is based on various theories advanced by a number of scholars who have tried to explain the phenomenon underlying talent management in organisations.

\subsection{Human Capital Theory}

'If you want a good job, get a good education.' This advice is given often to school children. Most of the advisers have never heard of human capital theory but believe strongly in it. Human capital theory specifies a particular mechanism through which education level is positively correlated with income: education increases skills, and these in turn increase productivity; higher productivity is then rewarded through higher earnings (Mincer, 1974). Early contributors to the theory such as (Becker, 1964) concluded that individual earnings were largely an outcome of how much workers invested in developing their skills and knowledge. Therefore, individuals with higher levels of human capital can contribute at a higher level in organisations. The potential value of human capital increases with job complexity, and with higher performance in complex jobs associated with greater differences in human capital (Hunter et.al., 1990).

\subsection{Social Capital Theory}

This term explains the adage it is not what you know, it is who you know.Social capital is the sum of the actual and potential resources embedded within, available through, and derived from the network of relationships possessed by an individual or social unit and the assets that may be mobilized through that network. (Lengnick-Hall and Lengnick-Hall, 2012) identify three key ways in which social capital can facilitate talent management: as a form of social control; as a support network for employees and providing access to information and other assets such as political insights.

\subsection{The Resource Based View}

The popularity of the resource based view of the firm has turned the focus on the black box of the firm the central premise of the resource based view addresses the question of why firms are different and how firms achieve and sustain competitive advantage. (Barney, 1991) Key resources have been identified as intangible assets such as client trust and relationships and capabilities or tangible resources such as skills and knowledge, technology and information. The resources based view was used to support organisation resources in the form of knowledge and skills that employees bring to the organisation. Effectively, this looks at valuable resources that are heterogeneous and not perfectly mobile (Peteraf, 1993). Talent management involves employee retention which meets the quality of the resources being immobile in the short run and possibly in the long run too.

\subsection{Summary of the Theories of the Concept}

Human capital theory identifies employees ${ }^{\text {ee }}$ potential to generate value for an organisation it works with the social capital theory and the resource based view to support the concept of talent management. Human capital theory identifies the human resources in an organisation as owners of human capital which can then be shared through mentoring and training to others in the organisation using the social capital theory. The resource based view identifies human resources as intangible assets that can lead to competitive advantages for a firm especially since they cannot be imitated and can be retained through certain practices which form part of talent management Talent management is a value creating process through training and development and other related practices.

\section{Empirical Review}

\subsection{Philosophical Foundation}

The philosophical foundation for most studies in talent management is pragmatism. Pragmatism uses mixed methods in research. Qualitative and quantitative methods are used when appropriate and can even be mixed because good social research requires the use of both to provide an adequate answer (Greene et.al,2005). A variety of data sources may be included and multiple perspectives are used to interpret results. Most of the studies in talent management adopt pragmatism as their research philosophy.

\subsection{Summary of Empirical Studies}




\section{International Journal of Science and Research (IJSR) \\ ISSN (Online): 2319-7064}

Index Copernicus Value (2013): 6.14 | Impact Factor (2014): 5.611

Table 1: Summary of Empirical Studies

\begin{tabular}{|c|c|c|c|c|c|}
\hline Researches & Thematic issues & $\begin{array}{l}\text { Philosophical } \\
\text { foundations }\end{array}$ & $\begin{array}{c}\text { Research } \\
\text { Methodology }\end{array}$ & Findings & Identified gaps \\
\hline $\begin{array}{c}\text { Bura and } \\
\text { Kireru } 2014\end{array}$ & $\begin{array}{l}\text { Challenges affecting } \\
\text { implementation of } \\
\text { talent management }\end{array}$ & Not stated & A case study & $\begin{array}{c}\text { Culture is a factor affecting talent } \\
\text { management }\end{array}$ & $\begin{array}{l}\text { This study can be carried } \\
\text { using a larger scope such } \\
\text { as an industry }\end{array}$ \\
\hline $\begin{array}{l}\text { Dhanabhakyan } \\
\text { and } \\
\text { Kokilambal } \\
2014\end{array}$ & $\begin{array}{l}\text { Existing talent } \\
\text { management } \\
\text { strategies practice } \\
\text { and its benefits } \\
\text { across industries }\end{array}$ & Not stated & Desk research & $\begin{array}{l}\text { Talent management practices will } \\
\text { vary across different levels and } \\
\text { industries hence the right approach } \\
\text { must be taken for better results }\end{array}$ & $\begin{array}{l}\text { The same study can be } \\
\text { carried out as a field } \\
\text { study }\end{array}$ \\
\hline $\begin{array}{l}\text { Dries, Cotton } \\
\text { and Oliveria } \\
2014\end{array}$ & $\begin{array}{l}\text { HR directors } \\
\text { understanding of } \\
\text { talent across } \\
\text { industries }\end{array}$ & Not stated & $\begin{array}{l}\text { Online survey } \\
\text { using snowball } \\
\text { sampling }\end{array}$ & $\begin{array}{c}\text { Meaning of culture is more culture- } \\
\text { specific and less consistent across } \\
\text { countries }\end{array}$ & $\begin{array}{l}\text { Random sampling would } \\
\text { have been more } \\
\text { appropriate for } \\
\text { generalisation of results }\end{array}$ \\
\hline $\begin{array}{l}\text { Hana and } \\
\text { Lucie } 2015\end{array}$ & $\begin{array}{l}\text { Investigating talent } \\
\text { management } \\
\text { philosophies }\end{array}$ & Not stated & $\begin{array}{l}\text { Two primary } \\
\text { surveys using } \\
\text { telephone } \\
\text { interviews and } \\
\text { electronic } \\
\text { questionnaire }\end{array}$ & $\begin{array}{c}\text { Czech organisations take a } \\
\text { conservative approach to talent } \\
\text { development }\end{array}$ & $\begin{array}{l}\text { A larger sample size } \\
\text { would allow for } \\
\text { generalisation of the } \\
\text { results }\end{array}$ \\
\hline $\begin{array}{l}\text { Hayashi and } \\
\text { Dolan } 2013\end{array}$ & $\begin{array}{c}\text { A processual } \\
\text { approach to } \\
\text { talenting } \\
\end{array}$ & Not stated & Desk research & $\begin{array}{l}\text { It is important to motivate } \\
\text { employees even when they are not } \\
\text { performing at peak performance }\end{array}$ & $\begin{array}{l}\text { This study can be carried } \\
\text { out using primary data } \\
\text { that is industry specific }\end{array}$ \\
\hline Ingram 2013 & $\begin{array}{l}\text { Talent Management } \\
\text { contingencies: } \\
\text { Empirical research } \\
\text { results }\end{array}$ & Not stated & $\begin{array}{l}\text { Cross sectional } \\
\text { survey using } \\
\text { secondary data } \\
\text { by the same } \\
\text { researcher } \\
\end{array}$ & $\begin{array}{c}\text { Internal and external contingencies } \\
\text { modify talent management } \\
\text { processes }\end{array}$ & $\begin{array}{c}\text { Primary data would have } \\
\text { been appropriate }\end{array}$ \\
\hline $\begin{array}{c}\text { Garg and Rani } \\
2014\end{array}$ & $\begin{array}{l}\text { Talent Management: } \\
\text { Empirical research } \\
\text { results }\end{array}$ & Not stated & Desk research & $\begin{array}{l}\text { To sustain outstanding business } \\
\text { results in a global economy } \\
\text { organisations will rethink and re- } \\
\text { invent their approaches to talent } \\
\text { management }\end{array}$ & $\begin{array}{l}\text { The same study may be } \\
\text { carried out in a specific } \\
\text { industry }\end{array}$ \\
\hline Oladapo 2014 & $\begin{array}{l}\text { Impact of talent } \\
\text { management on } \\
\text { retention }\end{array}$ & Not stated & $\begin{array}{l}\text { Online cross } \\
\text { sectional survey }\end{array}$ & $\begin{array}{l}\text { Effective talent management pays } \\
\text { off in employee retention which is } \\
\text { vital to profitability }\end{array}$ & $\begin{array}{l}\text { Only organizations with } \\
\text { talent management } \\
\text { programs included }\end{array}$ \\
\hline $\begin{array}{c}\text { Vivas-Lopez } \\
2014\end{array}$ & $\begin{array}{l}\text { Talent management } \\
\text { and team-work }\end{array}$ & Not stated & $\begin{array}{l}\text { Cross sectional } \\
\text { survey }\end{array}$ & $\begin{array}{l}\text { The explicit use of learning- } \\
\text { fostering tools such as talent } \\
\text { management helps build an } \\
\text { adequate context for organisational } \\
\text { knowledge creation }\end{array}$ & $\begin{array}{l}\text { Relationships among } \\
\text { multiple variables not } \\
\text { examined during data } \\
\text { analysis }\end{array}$ \\
\hline
\end{tabular}

\section{Conclusion and Recommendations}

\subsection{Conclusion}

The rapid technological development in the $21^{\text {st }}$ century led to a massive number of new products exceeding individuals ${ }^{\text {ee }}$ capability to trace them and employee competencies became the focus of attention, since business models that worked in the past are quickly becoming outdated and there are shifts in the world economy and population, hence talent management. Companies that master talent management will be well positioned for long-term growth in workforce performance for years to come. The concept of talent management is difficult to define since it is viewed from different perspectives and has varying interpretations of the same activities performed by different industries. While some adopt the exclusive approach, others opt for the inclusive approach. Regardless of the varying definitions it was generally agreed upon that talent management was necessary due to the retirement of the baby boomers, the rapid technological development and the scarcity of talent globally and this led to growth and adoption of the concept. The studies carried out have examined talent management both as an independent and as a dependant variable. The drivers of talent management can be identified broadly as: recruitment, training and development, performance management, succession planning, talent retention, work-life balance, employee engagement and rewards and recognition. The theories underlying the concept are human capital theory, social capital theory and the resource based view. The studies used pragmatism as their research philosophy with most combining quantitative and qualitative research methodology. Talent management is relatively new as a concept and there remains a lot to be done in terms of research.

\subsection{Recommendations}

Talent management is an area of study that is growing rapidly. However, studies are necessary to adequately define talent management and bring a concession between the exclusive and the inclusive views of talent management and determine the benefits of each of the views to organizations in various industries, and to different categories of workers. The implementation of talent management programs is not a one size fits all affair, it should vary depending on the Organisational Culture.

\section{Volume 5 Issue 1, January 2016}




\section{International Journal of Science and Research (IJSR) \\ ISSN (Online): 2319-7064}

Index Copernicus Value (2013): 6.14 | Impact Factor (2014): 5.611

\subsection{Proposed conceptualisation of Talent Management}

I propose a study on the effect of organizational Culture on Talent Management.Organisational culture is one of the key ,stable factors ${ }^{\text {ee }}$ which plays a critical role in everyday operations of organizations. Culture can be defined as ,the way we do things around here (Lundy and Cowling, 1996).

Career Management is described as a series of formal less formal activities designed and managed by the organization to influence the career development of employees thereby improving organizational effectiveness. Organizational career management develops and supports employee commitment (Sturges et.al., 2005).

Working environment is the standard of living of a work force. Work environment is also defined as an opportunity to exercise onees talent, an activity thought to be worth-while by individuals involved (Serey, 2006).

Reward management is concerned with the formulation and implementation of strategies and policies that aim to reward employees fairly, equitably and consistently in accordance with their value to the organization. An organized reward system should be fair, consistent and equitable in order to motivate and energize employees influencing their behaviour and attitude towards their job (Purwanti, et.al.,2010).

Work-life balance is a concept that includes proper prioritizing between work and lifestyle. The management of employee work-life balance requires organizations to recognize and account for the array of non-work roles that impact on their working lives (Higgins and Duxbury, 2005).

\subsection{Proposed Methodology}

This will be a cross sectional survey, which will adopt a descriptive research design. Primary data will be collected using a questionnaire in which both open ended and closed ended questions will be used to collect quantitative and qualitative data; to avoid the pitfalls of each data type and exploit the strengths of both. The research philosophy of choice will be pragmatism. The target population will be human resource managers in the public service in Kenya, and the stratified random sampling technique will be used. Stratified random sampling population is divided into two or more groups using a given criterion and then a given number of cases are randomly selected from each population subgroup (Mugenda and Mugenda, 2012). The population will be divided into three major categories which will be top management, middle management and lower level management.

\subsection{Proposed Conceptual Framework}

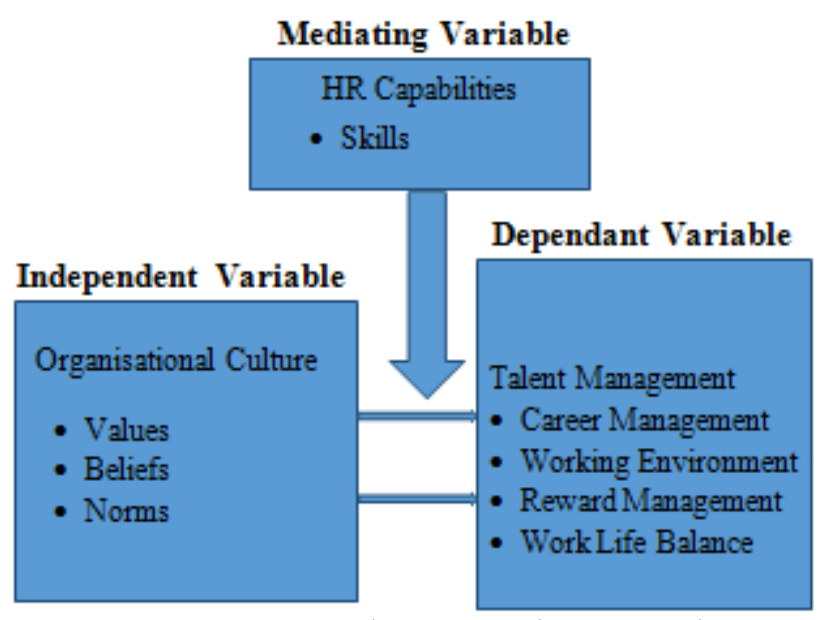

Figure 1: Proposed Conceptual Framework

\section{References}

[1] B.J.Barney, „Firm Resources and Sustained Competitive Advantagee, Journal of Management, (17), pp. 99-120, 1991.

[2] G. Becker, „Investment in human capital: A theoretical analysise, ,Journal of Political Economy, (70), pp. 9-49, 1964.

[3] H. Bula, J.N. Kireru, „An Empirical Study of Challenges affecting implementation of Talent Management in the Public Sector in Kenya: A case of Kenya Broadcasting Corporation ${ }^{\text {ee }}$, International journal of humanities and social sciences, 4(7), pp. 217-231, 2014.

[4] M. Dhanabhakyam., and K, Kokilambal,„A study on existing Talent Management practice and its benefits across industries ${ }^{\text {ee }}$ International Journal of Research in Business Management, 2(7), 23-36, 2014.

[5] Dries, N. Cotton, R, D.,Bagdadli, S., De Oliveira, M, Z. "HR Directors" understanding of „Talent": A crosscultural study"e, Global Talent Management, 3(2), 1528, 2014.

[6] Garg, D., Rani, K. (2014), Talent Management Empirical Research Results. International Journal of Management and Commerce Innovations, 2(1), 289295, 2014

[7] T. Ingram,,Talent Management Contingencies: Empirical Research Results ${ }^{\text {ec }}$. Croatia International Conference, 693-701, 2013.

[8] Motowidlo, S. J. Job performance. In W. C. Borman, D. R. Ilgen, R. J. Klimoski (Eds.), Handbook of psychology: Vol.12. Industrial and organizational psychology (pp. 39-53).Hoboken, NJ: John Wiley \& Sons, 2003

[9] M.A, Peteraf, The cornerstones of competitive advantage: A resource-based view. Strategic Management Journal. 14 (March): 179-191, 1993.

[10] D, Ulrich, „Human resource champions. The next agenda for adding value and delivering results ${ }^{c e}$, Boston: Harvard Business School Press, 1997.

[11] S, Vivas-López,, M. Peris-Ortiz, C. Rueda-Armengot, "Managing Talent for Organizational Learning", European Journal of International Management, 5(5), 540-557, 2011. 